\title{
List of plates
}

I La Petite Mort (1994)

page 41

2-3 Sitcom (1998)

$41-2$

4 Regarde la mer (1997)

5-6 Gouttes d'eau sur pierres brûlantes (1999) 43-4

7-8 8 femmes (2001) 44-5

9 Sous le sable (2000) $\quad 4^{6}$

Io Swimming Pool (2003) $\quad 46$

II $5 \times 2$ (2004) 47

I2 Le Temps qui reste (2005) 47

Plates 1 and 4 are reproduced by kind permission of Fidélité Films. All other images are reproduced by permission of Jean-Claude Moireau. 